\title{
Leprosy review
}

Author:
Lehlohonolo Makhakhe ${ }^{1,2}$
Affiliations:
'Department of Dermatology,
Faculty of Health Science,
University of the Free State,
Bloemfontein, South Africa
2 The South African Institute
of Dermatology,
Bloemfontein, South Africa
Corresponding author:
Lehlohonolo Makhakhe,
makhakhel@ @ufs.ac.za
smart phone or
Dates:
Received: 02 Apr. 2021
Accepted: 08 Aug. 2021
Published: 29 Oct. 2021
Read online.
How to cite this article:
Makhakhe L. Leprosy
review. S Afr Fam Pract.
2021;63(1), a5311. https://
doi.org/10.4102/safp.
v63i1.5311
Copyright:
C 2021. The Authors.
Licensee: AOSIS. This work
is licensed under the
Creative Commons
Attribution License.

Leprosy (Hansen's disease) can affect multiple organs and body structures. Skin signs are typically observed in the early phase of the disease, hence being the first identifiable signs to propel clinical suspicion. Leprosy predominantly affects the skin and peripheral nerves. The disease has been documented many centuries preceding the biblical era. Over many decades, the classification of Hansen's disease has changed as modern medical science evolved. Patients with leprosy are usually subjected to discrimination, rejection from society and can suffer from social stigma, poor quality of life (QoL), low self-esteem and permanent disfigurements. Studies have shown that leprosy has a significant negative impact on the patients' QoL. Leprosy is often not suspected by practicing clinicians because it is no longer emphasised in the medical curricula. In modern years, attention has gradually shifted from leprosy to tuberculosis (TB) and human immunodeficiency virus (HIV).

Keywords: leprosy; Hansen's disease; quality of life; self-esteem; HIV; TB.

\section{Introduction}

Hansen's disease is caused by an obligate intracellular organism called Mycobacterium leprae. The disease spectrum ranges between two poles, namely tuberculoid and lepromatous, depending on the patient's immunological response to M. leprae. ${ }^{1}$

Before the advent of antimicrobial therapy, patients confirmed with the disease were usually secluded from household contacts and communities at large, in fear of this condition being communicable.

In 2005, the World Health Organization (WHO) reported that leprosy was eliminated as a world public health problem. However, new cases are still seen to this day. Globally, to date, an average of 250000 new patients are reported annually. ${ }^{2}$ Incidence and prevalence of this condition differs considerably per country, noting that developing countries bear the biggest brunt of both new cases and that of patient on treatment.

Of concern is that little attention is paid to leprosy in the medical curriculum, this has been found to be the case in dermatology, rheumatology and neurology disciplines. As a result of the inadequate medical training, studies have found that clinical suspicion and subsequent diagnosis of leprosy is often delayed, resulting in permanent and debilitating complications. Lack of awareness is one of the main reasons for missing the diagnosis, even at a specialist level. ${ }^{2}$

\section{Discussion}

Hansen's disease occurs in all ages, in endemic countries such as Brazil, Nepal, India and Indonesia, cases typically present before the age of 35. The latency period between M. leprae exposure and overt clinical skin and nerve signs can range from 5 to 10 years depending on the type of leprosy. ${ }^{3}$

Over $80 \%$ of persons exposed to the bacterium $M$. leprae will likely resist the inoculation and infection. An estimated $17 \%$ of household contacts of individuals infected with leprosy are M. leprae polymerase chain reaction (PCR) positive on skin swabs and $4 \%$ on nasal swabs. Leprosy has a slight predilection for male adult patients (1.5:1) and monozygotic twins $(60 \%-85 \%){ }^{1}$

The mode of transmission is documented as ranging from tattooing, household contact and exposure to armadillo. Household contacts represent up to $28 \%$ of new cases, they are $4-10$ times at risk of infection in the long term. ${ }^{3}$ 
Because of the long latency period, it is possible for infected persons to only have evidence of the disease from nasal and skin swabs with no overt clinical signs. Hansen's disease causes pathology in humans and animals. To date, the causative organism, $M$. leprae has not been cultured in vitro. It grows best in temperatures of 30 degrees celsius or less, this explains its predilection to the feet, elbows, ears and testicles (in male) whilst sparing the midline and scalp. ${ }^{1}$

Table 1 gives latest available statistics demonstrating incidence of leprosy.

The diagnosis of leprosy is best made utilising the Ridley and Jopling scale and confirmation based on four components, namely clinical, bacteriologic, immunologic and histopathologic aspect.

\section{Clinical presentation}

There are two basic poles in classifying leprosy, namely lepromatous and tuberculoid leprosy. Patients tend to remain in one form throughout the course of the disease. Cellmediated immunity of the affected persons largely determines the type of leprosy the specific person will have. Nerve involvement is detected by enlargement of peripheral nerves and appearance of specific skin lesions that are usually associated with loss of sensation. ${ }^{1,2,3,5,6}$

Tuberculoid leprosy results from infection of an individual with high cell-mediated immunity, typified by less than five skin lesions, it can however be more extensive as seen in Figure 1.7,8

Hansen's disease may only involve the nerves; however, it is primarily a disease of peripheral nerves, skin and mucosa, particularly the upper respiratory tract. Skin lesions are usually the first clinical sign noticed and thus the main reasons that it is considered to be a dermatological disease. If left untreated, leprosy may progress causing permanent damage to the skin, the nerves, the limbs and the eyes. Tissue damage may occur because of $M$. leprae infiltration, but most of the damage is secondary to peripheral neuropathy (see Figure 4).

\begin{tabular}{lcccc}
\multicolumn{6}{l}{ TABLE 1: Leprosy statistics } & (2020) in South Africa. \\
\hline Province & Total & Male & Female & $\begin{array}{c}\text { Disability grading } \\
\text { at diagnosis }\end{array}$ \\
\hline Eastern cape & 6 & 2 & 4 & 4 \\
Free state & 0 & - & - & - \\
Gauteng & 8 & $\dagger$ & $\dagger$ & 1 \\
Kwazulu-Natal & 2 & - & 2 & - \\
Limpopo & 0 & - & - & - \\
Mpumalanga & 0 & - & - & $\dagger$ \\
North West & 1 & 1 & - & - \\
Northern Cape & 1 & - & - & - \\
Western Cape & 0 & - & - & - \\
\hline Total & 17 & - & - & \\
\hline
\end{tabular}

Note: Documented Leprosy Incidence in South Africa (updated 1 February 2021), courtesy of Mr. peter Laubscher (The Leprosy Mission)

$\dagger$, Information not reported.
The clinical course is typically insidious, either presenting with numbness before the skin lesions are clinically noticeable and before the peripheral nerves are palpable.

Secondary infections, following trauma, after sensory loss may result in tissue loss as bone, cartilage and bone resorption causing auto-amputation of fingers, toes and nasal collapse (see Figures 2 and $\left.3^{11}\right) .{ }^{9}$

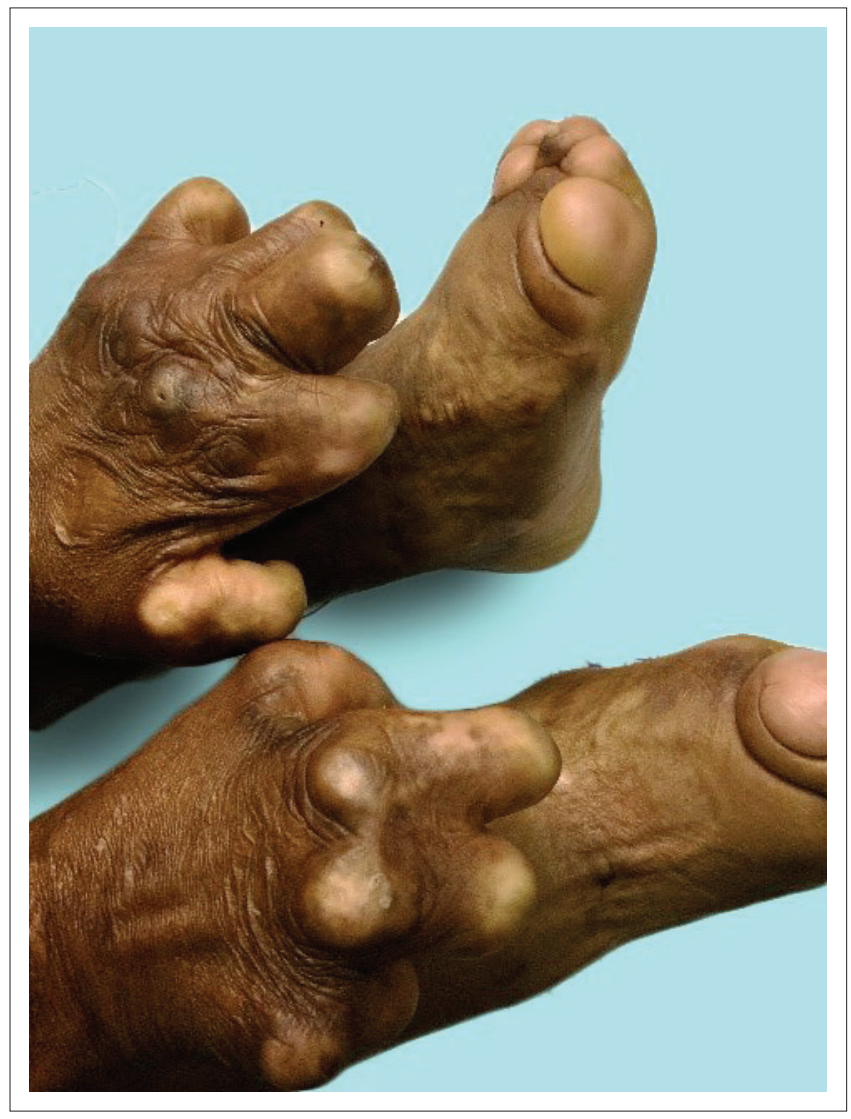

Source: Makhakhe L. African atlas, synopsis and practical guide to clinical dermatology. 1st ed Free State: African Brilliant Minds Publishers, 2020; p. 573-576. ISBN 978-0- 6399539-1-5. FIGURE 1: Debilitating complications of end-stage leprosy.

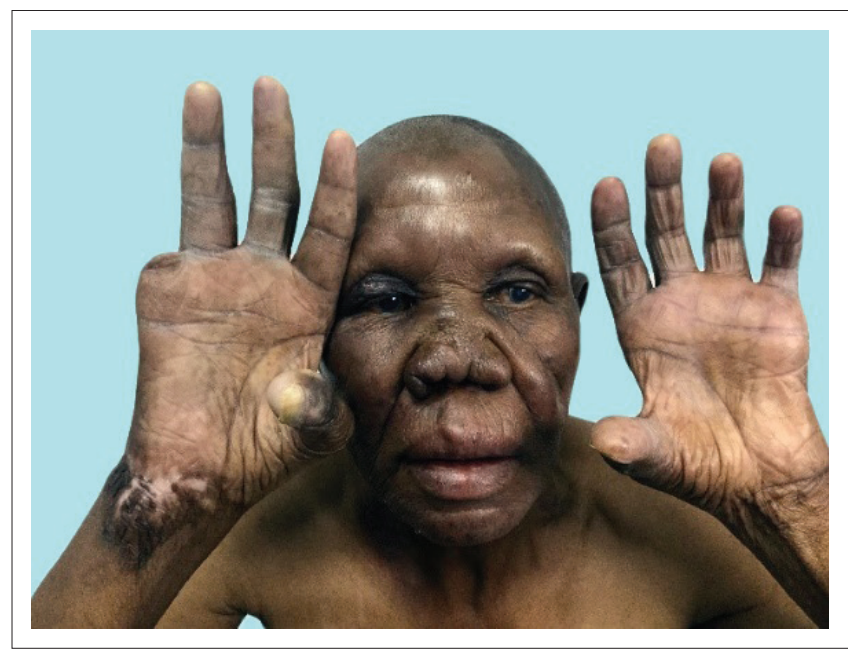

Source: Makhakhe L. African atlas, synopsis and practical guide to clinical dermatology. 1st ed. Free State: African Brilliant Minds Publishers, 2020; p. 573-576. ISBN 978-0- 6399539-1-5. FIGURE 2: Male patient with lepromateous leprosy, presenting with madarosis (loss of eyebrows), thickened dry skin, nasal congestion and auto-amputation of the little finger on the right hand. 
The early sensory changes are loss of light touch and temperature. Skin lesions usually begin as one ill-defined, hypopigmented, single patch that can also be erythematous. Furthermore, clinical interrogation may reveal either normal sensation or minimally reduced feeling, often causing disturbances in discerning between hot and cold sensation. A

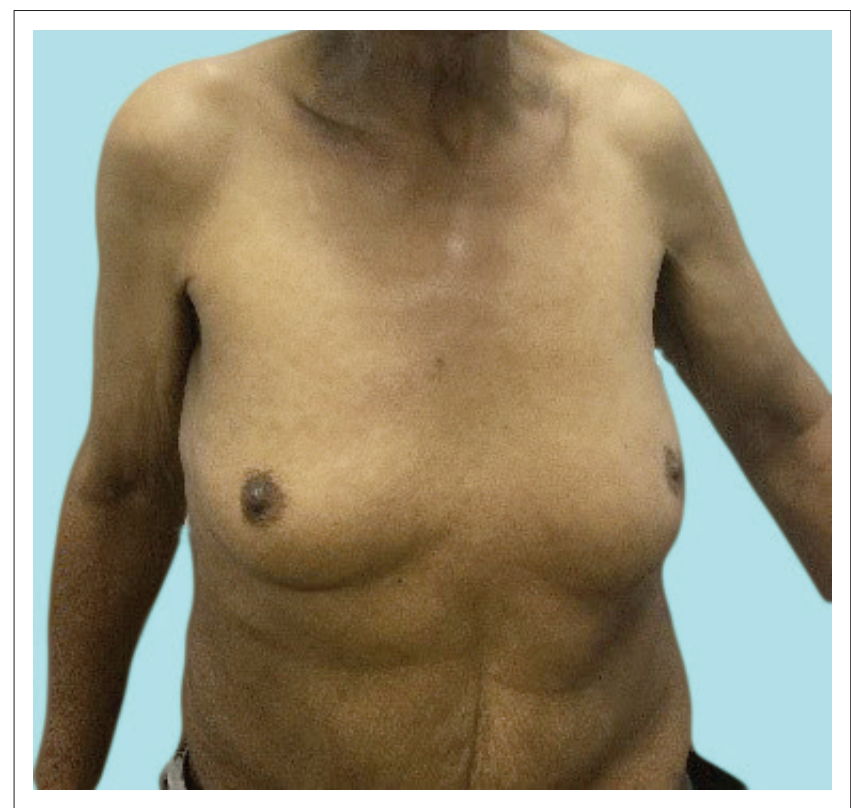

Source: Makhakhe L. African atlas, synopsis and practical guide to clinical dermatology. 1st ed. Free State: African Brilliant Minds Publishers, 2020; p. 573-576. ISBN 978-0- 6399539-1-5. FIGURE 3: Gynecomastia secondary to testicular infiltration by the bacterium.

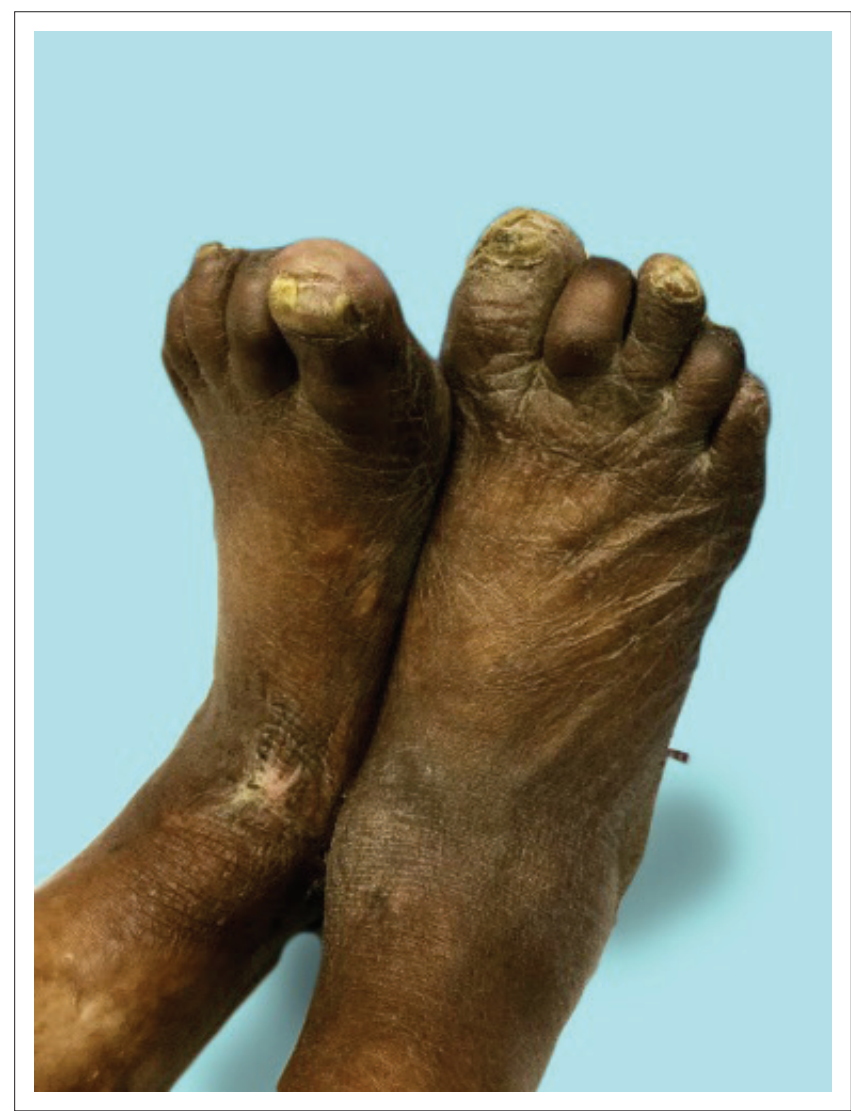

Source: Makhakhe L. African atlas, synopsis and practical guide to clinical dermatology. 1st ed. Free State: African Brilliant Minds Publishers, 2020; p. 573-576. ISBN 978-0-6399539-1-5.

FIGURE 4: Peripheral neuropathy with secondary nail dystrophy. typical lesion of tuberculoid leprosy is anhidrotic (dry skin), with reduced sensation and with secondary alopecia (hair loss). Nerve involvement often appears later, with enlarged and tender peripheral nerves either above or below the skin lesions. Lepromatous leprosy presents as a more severe form of leprosy, it is typically symmetrical, progresses slowly and usually takes longer to treat with higher rates of relapses. Of the two poles, lepromatous leprosy has a severe impact on quality of life (QoL) (see Figures 3, 5, 6, 7 and $8^{11}$ ).,3,7

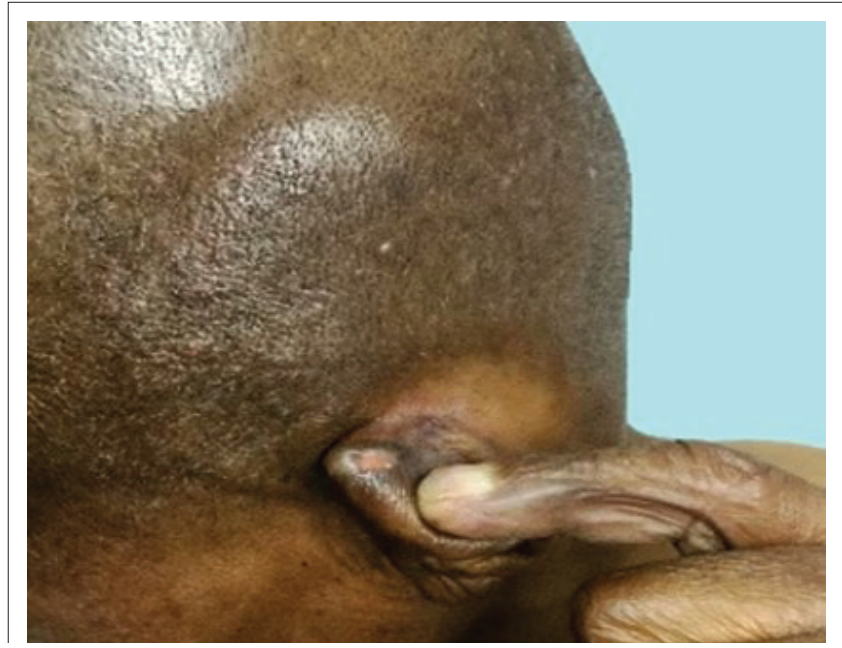

Source: Makhakhe L. African atlas, synopsis and practical guide to clinical dermatology. 1st ed. Free State: African Brilliant Minds Publishers, 2020; p. 573-576. ISBN 978-0- 6399539-1-5.

FIGURE 5: Ulcer on the left ear pinnae, typical area for $M$. leprae as it is cooler than the core body temperature.

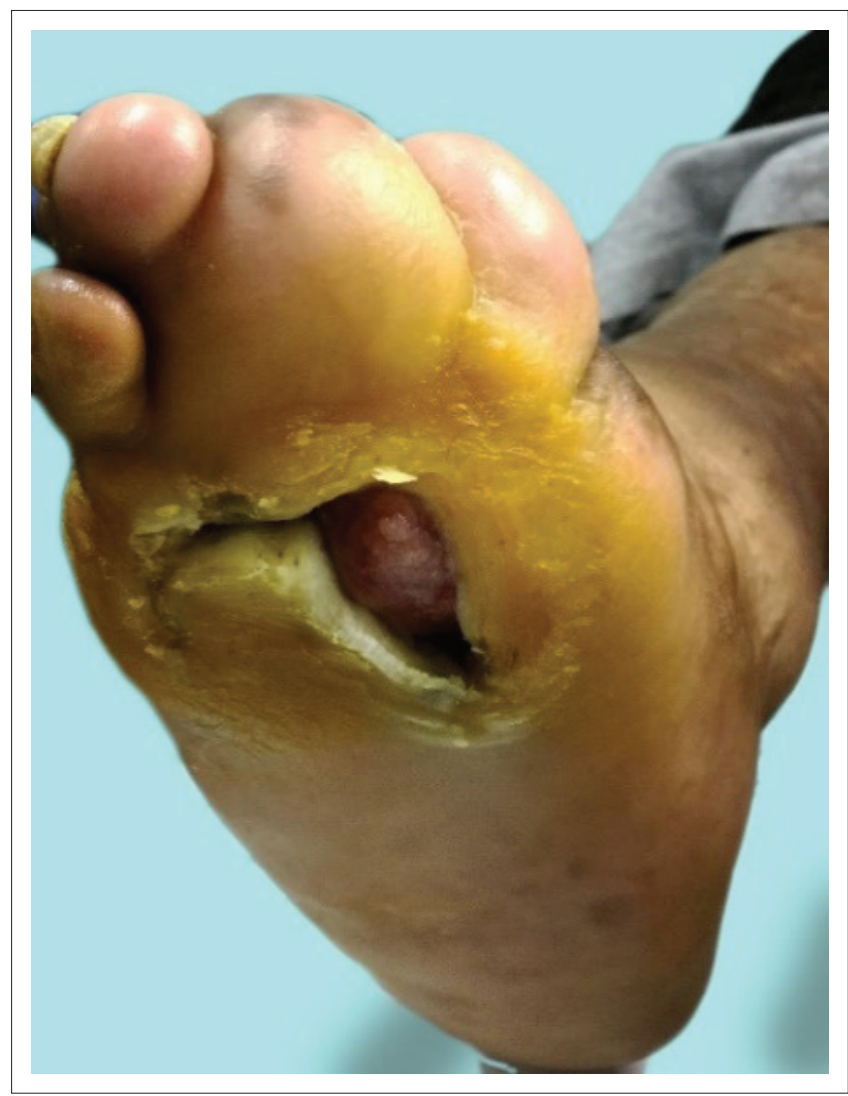

Source: Makhakhe L. African atlas, synopsis and practical guide to clinical dermatology. 1st ed. Free State: African Brilliant Minds Publishers, 2020; p. 573-576. ISBN 978-06399539-1-5.

FIGURE 6: Neuropathic ulcer. 


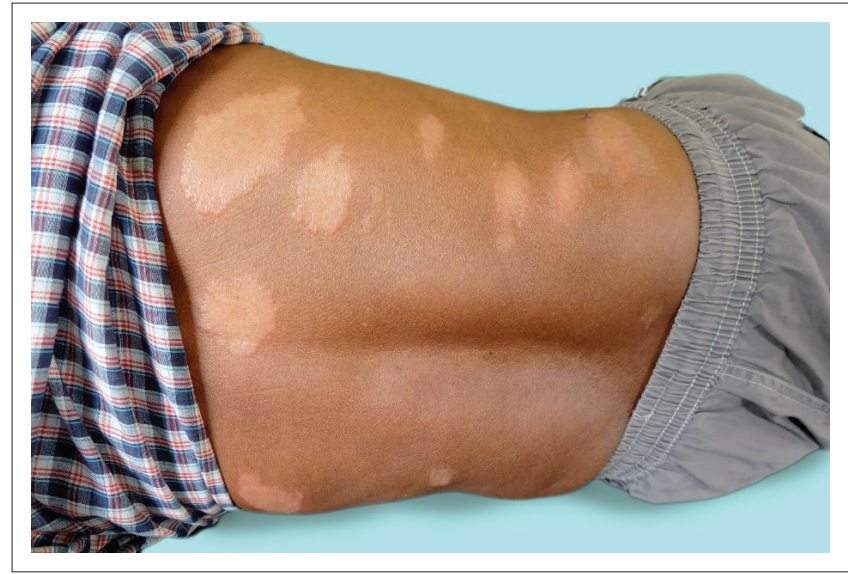

Source: Thadthiam P. Leprosy, skin of the patient Leprosy, The white band on the back of the man. [image on the Internet]. Shutterstrock. [cited]. Available from: https://www. shutterstock.com/image-photo/leprosy-skin-patient-white-band-on-736732867

FIGURE 7: Tuberculoid leprosy

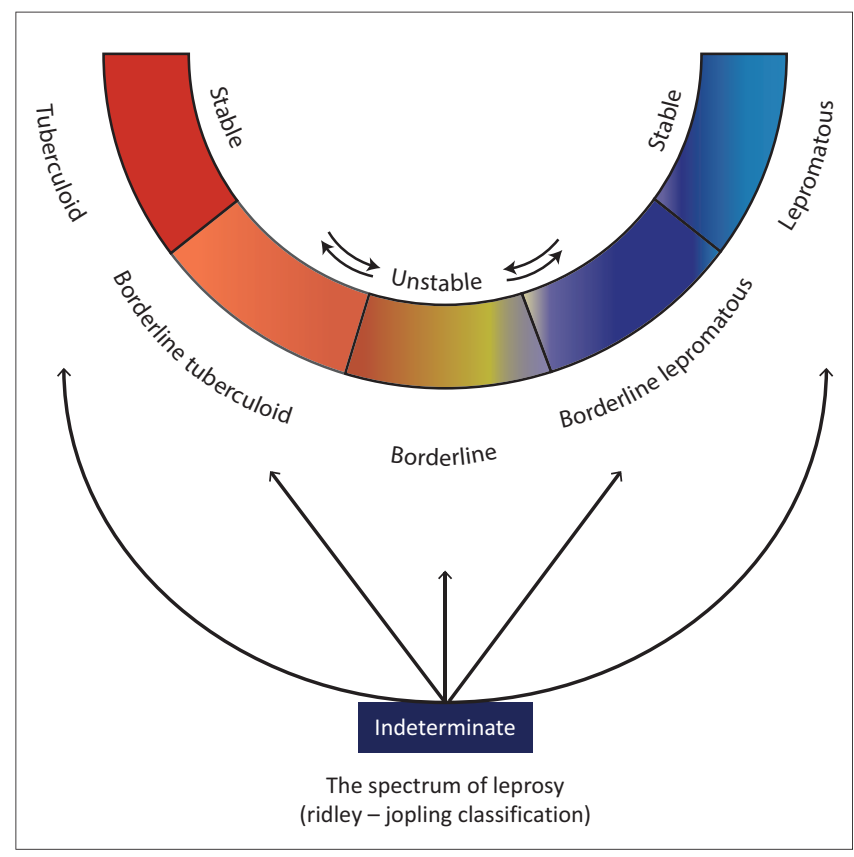

Source: Makhakhe L. African atlas, synopsis and practical guide to clinical dermatology. 1st ed. Free State: African Brilliant Minds Publishers, 2020; p. 573-576. ISBN 978-06399539-1-5.

FIGURE 8: Ridley-Jopling classification

\section{Common notable signs in leprosy}

The cardinal signs of leprosy are:

- Loss of sensation in a skin lesion

- Enlarged peripheral nerve

- Positive skin smears

Several studies have shown that the presence of antibodies to the M. leprae-specific phenolic glycolipid-I (PGL-I) correlates with the bacterial load of a leprosy patient. The majority of multibacillary (MB) patients have high levels of antibodies to PGL-I, whilst in general paucibacillary (PB) patients are seronegative. Studies monitoring the serum antibody levels during treatment further demonstrate this correlation of serum antibodies to PGL-I as indicators of the bacterial load: declining antibody levels during treatment correspond with
TABLE 2: Common signs of leprosy.

\begin{tabular}{|c|c|c|c|c|}
\hline \multirow[t]{2}{*}{ Age group } & \multirow[t]{2}{*}{ Drug } & \multirow[t]{2}{*}{ Dosage and frequency } & \multicolumn{2}{|c|}{ Duration } \\
\hline & & & MB & PB \\
\hline Adult & $\begin{array}{l}\text { Rifampicin } \\
\text { Clofazimine } \\
\text { Dapsone }\end{array}$ & $\begin{array}{l}600 \mathrm{mg} \text { once a month } \\
300 \mathrm{mg} \text { once a month } \\
\text { and } 50 \mathrm{mg} \text { daily } \\
100 \mathrm{mg} \text { daily }\end{array}$ & 12 months & 6 months \\
\hline $\begin{array}{l}\text { Children } \\
\text { (10-14 years) }\end{array}$ & $\begin{array}{l}\text { Rifampicin } \\
\text { Clofazimine } \\
\text { Dapsone }\end{array}$ & $\begin{array}{l}450 \mathrm{mg} \text { once a month } \\
150 \mathrm{mg} \text { once a month } \\
\text { and } 50 \mathrm{mg} \text { daily } \\
50 \mathrm{mg} \text { daily }\end{array}$ & 12 months & 6 months \\
\hline $\begin{array}{l}\text { Children } \\
\text { (<10 years or } \\
<40 \mathrm{~kg})\end{array}$ & $\begin{array}{l}\text { Rifampicin } \\
\text { Clofazimine } \\
\text { Dapsone }\end{array}$ & $\begin{array}{l}10 \mathrm{mg} / \mathrm{kg} \text { once a month } \\
6 \mathrm{mg} / \mathrm{kg} \text { once a month } \\
\text { and } 1 \mathrm{mg} / \mathrm{kg} \text { daily } \\
2 \mathrm{mg} / \mathrm{kg} \text { daily }\end{array}$ & 12 months & 6 months \\
\hline
\end{tabular}

Source: Belachew WA, Naafs B. Position statement: Leprosy: Diagnosis, treatment and follow-up Eur Acad Dermatol Venerol. 2019;33(7):1205-1213. https://doi. org/10.1111/jdv.15569

$\mathrm{MB}$, multibacillary; PB, paucibacillary.

declining bacterial indices. The observation that increasing levels of antibodies to PGL-I in patients can be associated with the development of relapses also indicates a relation between PGL-I antibody levels and the presence of M. leprae..$^{4,7}$

\section{Management}

Management of leprosy includes high index of suspicion, followed by clinical and histological confirmation. Once a diagnosis is confirmed, household members must also be examined whilst the source patient is started on treatment and appropriate monitoring for the full duration of the antibiotic chemotherapy (duration depending on the type of leprosy being treated). Antibiotics include dapsone, rifampicin and clofazimine (see Table 2). ${ }^{2}$ It is also common that leprosy will spontaneously remit in the absence of active treatment.

The first known historical treatment that had some effect was chaulmoogra oil, dating back to 600 BC. The effect was minimal in different preparations used, but some success was obtained in PB leprosy.

The first effective antibiotic, intravenous sulfone - promin appeared in 1943, this was followed by an oral derivate called dapsone, which became the standard treatment. Upon the appearance of secondary dapsone resistance in the 1970s together with the ready availability of rifampicin, the use of combined regimens was recommended. However, it was not until 1982 that the WHOs Chemotherapy Study Group recommended the combined use of the two drugs without clofazimine. ${ }^{3}$

In cases of rifampicin resistance, levofloxacin and minocycline can be strongly considered as regimen substitution. South Africa uses WHO's recommendations in its treatment of leprosy.

\section{World Health Organization's recommended treatment for leprosy}

\section{Reoccurrence}

Even after appropriate treatment, there may be a relapse. This can be attributed to a few factors, such as resistance, persisters, re-infections or classification misdiagnosis with subsequent under treatment. 


\begin{tabular}{|c|c|c|c|c|}
\hline Cutaneous & Ophthalmology & Nasal & Central nervous system & Other \\
\hline Erythematous plaques & Keratitis & Nasal congestion & Skin numbness & $\begin{array}{l}\text { Testicular infiltration with } \\
\text { secondary }\end{array}$ \\
\hline Hypopigmented macules with or without loss of sensation) & Lagophthalmos & Nasal ulceration & Peripheral neuropathy & azoospermia \\
\hline Nodules (histoid leprosy) & & & Palpable peripheral nerves & $\begin{array}{l}\text { Disability will usually be } \\
\text { inevitable, if untreated }\end{array}$ \\
\hline Loss of hair on affected site & & & Nerve damage & Join destruction \\
\hline Dry skin on affected areas (anhidrosis) & & & Neuropathic ulcers & \\
\hline \multicolumn{5}{|l|}{ Leonine face } \\
\hline \multicolumn{5}{|l|}{ Autoamputation of digits } \\
\hline \multicolumn{5}{|l|}{ Diffuse infiltration of the skin } \\
\hline $\begin{array}{l}\text { Nail changes (onycholysis, brittle nails, subungual haematoma, onychauxis, } \\
\text { onychogryphosis, racket nail, pterygium unguis, ectopic nail, spicule nail, } \\
\text { anonychia, thinning, longitudinal splits, atrophy, diffuse lunula, leukonychia, } \\
\text { hapalonychia and pallori }\end{array}$ & & & & \\
\hline
\end{tabular}

Source: Makhakhe L. African atlas, synopsis and practical guide to clinical dermatology. 1st ed. Free State: African Brilliant Minds Publishers, 2020; p. 573-576. ISBN 978-0- 6399539-1-5. FIGURE 9: Common signs of leprosy.

In general, the reoccurrences are sensitive to the original multidrug therapy treatment (MDT). In cases of suspected resistance, PCR test is available. Resistance against clofazimine has not yet been convincingly documented. The main drug in treating multibacillary (MB) leprosy is rifampicin, the same key drug that forms the cornerstone in treating tuberculosis (TB). $4,7,10$

\section{Reactions}

There are two types of reactions, these usually follow antibiotic therapy.

Type I leprosy reaction (T1R) is also known as reversal reaction, it represents an enhanced cell-mediated immune response to the bacterium. If the reaction occurs as a borderline disease shift towards the lepromatous pole, then they are referred to as downgrading reactions and if this is because of antibiotic commencement, then they are called reversal reactions. Type II leprosy reaction (T2R), also called erythema nodosum leprosum (ENL), these are usually seen in lepromatous leprosy cases believed to be induced by circulating immune-complex mediated factors.

\section{Conclusion}

Bacille Calmette-Guérin (BCG) vaccination remains the best prophylactic therapy in many areas. Rifampicin prophylaxis for close contacts is still highly recommended by $\mathrm{WHO}$, although majority (> 80\%) will not contract the infection even without prophylaxis.

A useful tip to keep in mind is that it is rare to have nerve enlargement in other skin diseases. Clinicians need to keep leprosy in mind when confronted with any of the clinical signs as listed in Figure 9, more so when in combination.

Clinicians need to have an index of suspicion so that the infection can be eliminated and ultimately eradicated. Early diagnosis and treatment may lead to less complications and a reduced risk of infection to close contacts. Awareness campaigns and coverage of the disease in both undergraduate and postgraduate programme is important in combating this chronic and often debilitating infection.

\section{Acknowledgements Competing interests}

The author declares that he has no financial or personal relationships that may have inappropriately influenced him in writing this article.

\section{Authors' contributions}

This article is my original work to create awareness amongst general practitioners.

\section{Ethical considerations}

This article followed all ethical standards for research without direct contact with human or animal subjects.

\section{Funding information}

This research received no specific grant from any funding agency in the public, commercial or not-for-profit sectors.

\section{Data availability}

Data collected from Leprosy mission. No codes used or unique identifiers.

\section{Disclaimer}

The views and opinions expressed in this article are those of the author and do not necessarily reflect the official policy or position of any affiliated agency of the author.

\section{References}

1. El Darouti MA, Hussein S, SR Al Tahlang, et al. Clinical study of nail changes in leprosy and comparison with nail changes in diabetic patients. Eur Acad Dermato Venerol. 2011;25(3):290-295. https://doi.org/10.1111/j.1468-3083.2010.03783

2. Belachew WA, Naafs B. Position statement: Leprosy: Diagnosis, treatment and follow-up. Eur Acad Dermatol Venerol. 2019;33(7):1205-1213. https://doi. org/10.1111/jdv.15569

3. James W, Berger T, Elston D. Andrews' diseases of the skin. 11th ed. Philadelphia: Elsevier Saunders; 2011, Chapter 17, p. 334. ISBN 9781437703146.

4. BuÈhrer-SeÂkula S, Cunha MGS, NT Foss, et al. Dipstick assay to identify leprosy patients who have an increased risk of relapse. Trop Med Int Health. 2001;6(4):317-323. https://doi.org/10.1046/j.1365-3156.2001.00704.x 
5. An GJ, Ma HJ, SX Xiao, et al. Quality of life in patients with lepromatous leprosy in China. Eur Acad Dermatol Venerol. 2010;24(7):827-832. https://doi.org/10.1111 j.14683083.2009.03534

6. Sehgal VH, Jain MK, Manog K, et al. Evolution of the classification of leprosy. Int Dermatol. 1989;28(3):161-167. https://doi.org/10.1111/j.1365-4362.1989. tb02452.x

7. Parkash OM. Classification of leprosy into multibacillary and paucibacillary groups: An analysis. 2008. Fed Eur Microbiol Soc. 2008;55(1):1-5. https://doi. org/10.1111/j.1574-695X.2008.00491.x
8. Thadthiam P. Leprosy, skin of the patient Leprosy, The white band on the back of the man. [image on the Internet]. Shutterstrock. [cited 2019 Dec 21]. Available the man. [image on the internet]. Shutterstrock. [cited 2019 Dec 21]. Available from: https://www.shutterstock.com/image-photo/leprosy-skin-patient-white-
band-on-736732867

9. Ghorpade S. Inoculation (tattoo) leprosy: A report of 31 cases. Eur Acad Dermatol Venerol. 2002;16(5):494-499. https://doi.org/10.1046/j.1468-3083.2002.00548.x

10. No date [cited 2021 Jan 4]. Available from: http://www.brilliantminds.co.za

11. Makhakhe $L$. African atlas, synopsis and practical guide to clinical dermatology. 1st ed Free State: African Brilliant Minds Publishers, 2020; p. 573-576. ISBN 978-0-6399539-1-5. 